\title{
Fantastical materializations: Interoceanic infrastructures in the Ecuadorian Amazon
}

DOI:

$10.1177 / 0263775817695102$

\section{Document Version}

Accepted author manuscript

Link to publication record in Manchester Research Explorer

\section{Citation for published version (APA):}

Wilson, J., \& Bayón, M. (2017). Fantastical materializations: Interoceanic infrastructures in the Ecuadorian Amazon. Environment and Planning D: Society and Space, 35(5), 836-854.

https://doi.org/10.1177/0263775817695102

\section{Published in:}

Environment and Planning D: Society and Space

\section{Citing this paper}

Please note that where the full-text provided on Manchester Research Explorer is the Author Accepted Manuscript or Proof version this may differ from the final Published version. If citing, it is advised that you check and use the publisher's definitive version.

\section{General rights}

Copyright and moral rights for the publications made accessible in the Research Explorer are retained by the authors and/or other copyright owners and it is a condition of accessing publications that users recognise and abide by the legal requirements associated with these rights.

\section{Takedown policy}

If you believe that this document breaches copyright please refer to the University of Manchester's Takedown Procedures [http://man.ac.uk/04Y6Bo] or contact uml.scholarlycommunications@manchester.ac.uk providing relevant details, so we can investigate your claim.

\section{OPEN ACCESS}


Fantastical Materializations: Interoceanic Infrastructures in the Ecuadorian Amazon

This paper explores the entanglement of dreams and reality in the production of economic infrastructures. It focuses on the Manta-Manaus multimodal transport corridor, which is currently being constructed between the Pacific coast of Ecuador and the Atlantic coast of Brazil, with the aim of integrating the Amazon into global production networks. Drawing on extensive field research conducted in Ecuador, we develop a fantastical materialism, as a theoretical and methodological approach to the intertwining of fantasy and materiality through which the spaces of capital are conceived, constructed, and brought to ruin. MantaManaus is revealed not only as a technocratic accumulation strategy, but also as a seductive dream of planetary integration and geographical freedom. This dream has become ensnarled in the material dynamics of uneven geographical development, and its infrastructures have been repurposed for the expansion of the oil frontier. The Real of Capital thus advances through the creative destruction of its own fantasies.

Keywords: Fantastical materialism; infrastructure; fantasy; Real of Capital; Ecuador; Amazon

\section{Towards a fantastical materialism}

Only dreamers move mountains.

- Molly, in Werner Herzog's Fitzcarraldo

Carlos Fermín had a dream that would not let him sleep. ${ }^{1}$ Like the hero of Fitzcarraldo, who tried to open a tract of the Peruvian Amazon to rubber exploitation by dragging a steamship over a mountain, Fermín was "planning something geographical". ${ }^{2}$ He had spent decades transporting the machinery and materials of the Amazonian oil industry along the vast network of rivers that surround the Brazilian jungle city of Manaus. In 2001 he was contracted for the Herculean task of transporting a 127-ton generator over 2,000 kilometers upriver to the oil fields of the Ecuadorian

\footnotetext{
${ }^{1}$ A pseudonym has been used in this case. All other names are real. The pseudonym refers to Carlos Fermín Fitzcarrald, the Peruvian rubber baron on whom Werner Herzog based the character of Fitzcarraldo.

${ }^{2}$ On his way upriver towards the mountain over which he will drag his steamship, Fitzcarraldo spends a night in a Jesuit mission. One of the monks asks what he is doing in this remote part of the Amazon. Fitzcarraldo responds: "I'm planning something geographical".
} 
Amazon. No-one had ever attempted such a feat, and those who knew the Napo - a tributary of the Amazon that Fermín would have to enter in Peru - warned him that its upper reaches could not be navigated by vessels of that size. But Fermín proved them wrong, arriving in Ecuador with his cargo after a grueling month-long journey.

On his return to Manaus, Fermín became "preoccupied" with an idea. "I couldn't sleep well", he recalls, "The belief that the river was not navigable was an enormous lie. It was too much for me to bear... God had granted everything I had asked for. Good children, a house, a farm... I had everything. But now there was something in my head that would not leave me in peace." Fermín had realized that the navigability of the Napo opened the possibility of an interoceanic corridor, beginning from Manta, on the Pacific coast of Ecuador, crossing the Ecuadorian Andes by road, transferring to river at an Amazonian port on the Napo, continuing to Manaus, and concluding in the Atlantic port of Belem. The corridor would "commercialize" the Amazon, which Fermín describes as "a beautiful world of wealth". He remembers telling himself that "if you see the light, and your conscience tells you to do something... you must do it... This vision that God has given you is not your own, it is God's, and if you do not follow it you will not be happy". ${ }^{3}$ In 2004, Fermín abandoned his life in Brazil, and travelled back upriver to Ecuador, where he settled in Providencia, an isolated indigenous community on a broad curve of the Napo. There he set to work clearing the land, and began to search for allies in his quest to make Providencia the Amazonian port of his interoceanic corridor. He called the corridor 'Manta-Manaus'.

Ten years later, in January 2015, we visited Fermín in Providencia. Outside the oil town of Shushufindi we turned onto a newly completed highway that cut smoothly through 46 kilometers of jungle. At the end of the road a makeshift sign announced our arrival at the 'International Port of Providencia'. Ten hectares of rainforest had been levelled, and a grid of iron girders had been

\footnotetext{
${ }^{3}$ Carlos Fermín. Interview: 9 February 2015, Providencia, Ecuador.
} 
set into the river in preparation for the construction of the dock. In 2007 the Manta-Manaus corridor had been designated by Rafael Correa, the newly elected President of Ecuador, as one of the emblematic projects of his administration, and now the state was financing the road and port infrastructure required for its creation. Incredibly, it seemed that Fermín's extravagant dream had come true. He emerged from the back door of his simple home, hastily pulling on a crumpled shirt with his name and 'Manta-Manaus' embroidered on the back. We sat down to talk in a ramshackle porch with views across the wide sweep of the river and the vast rainforest beyond. "They used to call me a fat slobbering idiot (gordo baboso)! An imbecile!" he told us, laughing. "But now I'm a wise man! 'Watch out for that Brazilian guy', they say, 'he's a wise man, a genius!'”4

This paper narrates the story of Manta-Manaus, as a means of exploring the entanglement of reality and dreams in the production of economic infrastructures. The significance of this intertwined relationship has been underestimated or misconstrued in much of the critical literature on infrastructural development. In recent years, an increasingly influential literature has identified transnational infrastructure projects like Manta-Manaus as elements of an emergent geography of "extended" or "planetary" urbanization, characterized by the implosion of urban agglomerations and the explosion of infrastructural networks at the limits of planetary space (Arboleda 2016; Brenner 2013; Kanai 2014; Monte-Mor 2014). This process is conceptualized in terms of the technocratic construction of "operational landscapes" (Brenner and Schmid 2015: 167), through the implementation of "large-scale territorial planning strategies" (Brenner 2013: 20). Yet this account of infrastructural development overlooks the extent to which such processes are infused with idiosyncratic fantasies and hubristic ambitions, despite the fact that vast infrastructure projects have long been associated with obsessive visions that exceed the

\footnotetext{
${ }^{4}$ Carlos Fermín. Interview: 9 February 2015, Providencia.
} 
instrumental rationalities of capitalist calculability and territorial domination (Berman 1982: 3786).

In contrast to the literature on planetary urbanization, the "ethnography of infrastructure" (Star 1999) emphasizes that "roads and railways are not just technical objects... They encode the dreams of individuals and societies and are the vehicles whereby those fantasies are transmitted and made emotionally real" (Larkin 2013: 333). This literature tends to locate the imaginary and affective dimensions of these infrastructures in the everyday lives of construction workers and local populations (Dalakoglou and Harvey 2012; Harvey and Knox 2012). Yet the case of MantaManaus demonstrates that the logic of such infrastructures is permeated with its own dreams and desires, which become ensnarled in complex and counterintuitive materializations. In common with the ethnography of infrastructure, we aim to trace the knotted plots through which the spaces of capital are conceived, constructed and brought to ruin, and to draw attention to the failures and absurdities of grandiose infrastructural megaprojects, in contrast to their heroic selfrepresentations. The case of Manta-Manaus, however, suggests that the paradoxes and incongruities of such projects are due less to their collision with "unruly landscapes and citizens" (Harvey and Knox 2012: 529), than to the internal antagonisms of capitalist development, in which ideological fantasies are undermined by the contradictions that they conceal.

This paper develops a fantastical materialism, as an alternative approach to the intertwining of fantasy and materiality in the capitalist production of space. Fantastical materialism begins from a historical geographical materialist understanding of the nature of capitalist socio-spatiality, according to which the endless accumulation of capital is achieved through the production of an increasingly intensive and extensive system of spatial infrastructures, through which the contradictions of capital are expressed in a turbulent flux of creative destruction and uneven geographical development (Harvey 1982; Smith 1984). Drawing on elements of the 
psychoanalytical critique of ideology, fantastical materialism explores the ways in which these dynamics are both obscured and operationalized by ideological fantasies, such as the dream of an interoceanic corridor with which this paper began. The psychoanalytical concept of fantasy does not correspond to the commonsense understanding of fantasies as idle daydreams of imaginary worlds. On the contrary, ideological fantasies are constitutive of social reality itself, functioning as the frames through which we experience the world as coherent and meaningful, and organized as a protection against the Real, understood as the unsymbolized antagonisms and repressed drives against which 'reality' is symbolically constituted (Žižek 1989; 1997). In the symbolic universe of contemporary global capitalism, as Slavoj Žižek has argued, "'reality' is the social reality of the actual people involved in the production process, while the Real is the... spectral logic of Capital which determines what goes on in social reality" (Žižek 1999: 331). The phantasmatic dimensions of the capitalist production of space thus evolve in a tangled relationship with the Real of Capital, through which ideological fantasies simultaneously conceal and produce the very forces that undermine them and "condemn them to ultimate failure" (Žižek 1997: 124).

The concept of 'fantastical materialism' is apparently oxymoronic. After all, within the Marxian tradition, materiality has long been regarded as the stern domain of history and dialectics, while fantasy has tended to be dismissed "as ungrounded supposition, lacking in foundation, not solid enough" (Rose 1996: 5). Fantastical materialism is only one of several recent attempts to disrupt this ossified division. Andy Merrifield, for example, has called for a 'magical Marxism', based on the creation of "new magical geographies of the imagination" (Merrifield 2011: 14), and has drawn on this approach in his interpretation of planetary urbanization (Merrifield 2013). Jane Bennett has similarly celebrated the uncanny and transcendent moments of everyday life in countering dominant understandings of capitalist society as a "disenchanted world" (Bennett 2001: 8), and her work on 'enchanted materialism' has informed the ethnography of infrastructure (Harvey and Knox 2012; Kochore 2012). In contrast to these approaches, however, fantastical materialism 
understands enchantment, not as a transgressive aesthetic that disrupts the "rationalized description of material and social phenomena" (Harvey and Knox 2012: 523), or that subverts "the tumult of capitalist modernity" (Merrifield 2011: 21), but as symptomatic of the uncanny character of capitalist modernity itself, in which "it is the self-propelling metaphysical dance of Capital... that provides the key to real-life developments and catastrophes" (Žižek 2006: 383).

Like magical Marxism, fantastical materialism draws inspiration from magical realism, but understands this tradition not as the conversion of "reality into... phantasmal subjective visions" (Merrifield 2008: 381), but as a critical methodology that seeks to reveal the phantasmatic constitution of 'reality' itself, through a depth of clarity grounded in the "materiality of literary realism" (Zamora and Faris 1995: 3). This approach is again at odds with much of the Marxist tradition. As James Ferguson has noted, orthodox Marxism has tended to assume that "things simply snap into place because Capital 'needs' them to do so", which has frequently resulted in a failure to comprehend the "surprising and ironic" twists and turns of capitalist development (Ferguson 1994: 13-16). Acknowledgement of the indispensability of detailed empirical research, however, need not entail the abandonment of Marxian theory. As Žižek argues, "the highest form of ideology does not reside in getting caught in ideological spectrality, forgetting about its foundation in real people and their relations, but precisely in overlooking this Real of spectrality and in pretending to address 'real people with their real worries'"' (Žižek 2008a: 13).

Fantastical materialism attempts to tread a path between these two positions, based on the magical realist premise that the spectral and phantasmatic dimensions of socio-spatial reality are to be accessed precisely through meticulous attention to empirical detail. To this end, this paper draws on eighty-four semi-structured interviews conducted in 2015 with actors at all levels of the planning and implementation of Manta-Manaus, and with mestizo colonizers and members of indigenous communities affected by the project, as well as business press reports, internal 
government documents, and extensive field notes taken during our travels along the length of the Ecuadorian section of the corridor. ${ }^{5}$ Yet the depiction of a reality permeated by fantasy and spectrality is not only a matter of content, but also a question of form. Like magical realism, fantastical materialism therefore aims to combine descriptive clarity with a style that conveys the uncanny dimensions of the reality that it seeks to describe. As Fredric Jameson (2014) has observed, "A work has content. It has raw material... And the content already has a form inside it... The writer does not impose a form on it. The writer draws the form out of the very content itself."

Rather than forcing the world into a preconceived framework, fantastical materialism seeks to allow theory to breathe through the narration of events. These preliminary ideas are therefore only intended to provide a minimal map of our theoretical and methodological terrain, in order to contextualize the story that we have already begun, and which we will now resume. This story traces three twists in the relationship between fantasy and reality in the case of Manta-Manaus. The first twist explores the constitutive role of fantasy in the production of economic infrastructures, by revealing the ways in which a shared dream of planetary integration and geographical freedom succeeded in convincing politicians, entrepreneurs and indigenous communities to contribute to the construction of the interoceanic corridor. The second twist brings this fantasy into conflict with the Real of Capital, by uncovering the tangled web of intercapitalist competition, geopolitical rivalry, and recalcitrant nature that has contributed to the failure of Manta-Manaus. The third twist illustrates the ambiguous relationship between fantasy and the Real of the drive, by demonstrating how the law of value has operated through the destruction of Manta-Manaus and the repurposing of its infrastructures for the expansion of the

\footnotetext{
${ }^{5}$ The field research was conducted while working for the National Centre of Strategies for the Right to Territory (CENEDET), a research institute directed by David Harvey, and established on the invitation of the Ecuadorian government. Our location within the Ecuadorian state apparatus facilitated extensive access to government ministries and private companies, and provided a unique insight into the internal contradictions of Manta-Manaus and other spatial projects. For an account of the CENEDET experiment, see Wilson 2017.
} 
oil frontier. We conclude by weaving these twists more tightly into the fabric of a fantastical materialism, before teasing out the hidden thread of a disenchanted utopia.

\section{The El Dorado Project}

The Amazon Basin covers an area of seven million square kilometers. It contains the world's greatest river and most expansive tropical forest, and is one of the most biodiverse places on the planet. Beyond these brute material facts, however, the Amazon is also a "forest of desires...

imbued with passion [by] the symbolic content of the dreams that it ignites" (Hecht and Cockburn 1990: 1). Since its colonial discovery in the early $16^{\text {th }}$ century, the region has been framed in the capitalist imaginary as a land of superabundant natural wealth, and it has long been a privileged site for Promethean projects and utopian experiments staged by ruthless pioneers and romantic visionaries (Browder and Godfrey 1997; Grandin 2009). Of all these quixotic escapades, the most iconic and enduring has been the search for El Dorado. In 1541, the Spanish conquistadors Gonzalo Pizarro and Francisco de Orellana set out from what is now the Ecuadorian capital of Quito, descending from the Andes to the Amazon in search of this mythical cornucopia filled with unimaginable quantities of gold. The expedition was soon in desperate straits, and Pizarro sent Orellana down the River Coca in search of food and supplies. At the confluence with the Napo, Orellana resolved not to return, and forged on into the depths of the Amazon in search of the Atlantic coast, which he finally reached eighteen months later (Ainsworth 1934; Smith 1990).

In the late $19^{\text {th }}$ century, the rubber boom launched a second wave of expeditions to the Ecuadorian Amazon in search of "elastic gold", which came to an end in the early twentieth century, when the region was outcompeted by British colonies in East Asia (Russotto 2013: 133). In 1967, extensive oil deposits were discovered in the northern Ecuadorian Amazon. As Michael Watts observes, "El Dorado had been located, and it was in an oil well" (Watts 1994: 203). The oil price collapsed in the early 1980s, contributing to a national economic crisis that resulted in the 
neoliberalization of the Ecuadorian economy (Perreault and Valdivia 2010). Yet El Dorado continued to haunt the dreams of capital. In the late 1990s, an Ecuadorian entrepreneur called Augusto Celís became fascinated with the story of Pizarro and Orellana's original search for El Dorado, and grew convinced of the possibility of opening an interoceanic corridor along Orellana's route to the Atlantic. We visited Celís in Quito in 2015. He was old and sickly, and the walls of his musty office were covered with faded maps of the Amazon, on which the route of his fantasy was etched in red pen. Celís told us that he had decided to call his plan 'Proyecto El Dorado' in honour of the conquistadors' original mission. "We weren't looking for El Dorado", he added. "I didn't do this with the aim of making money. I just fell in love with an idea". ${ }^{6}$ The El Dorado Project soon became an obsession, and Celís went "knocking on every door" to promote his plan. At a trade fair in Manaus in the early 2000s he met Carlos Fermín, who, as we have seen, was already obsessed with the same vision. Together they created the Corporación Ecuatoriano Amazónica, purchasing twelve hectares of riverside land in the village of Providencia for the construction of their port, and forming an alliance with the Manta Port Authority (APM), which manages the Manta port on the Pacific coast of Ecuador. At this point, the scheme was renamed 'Manta-Manaus'.

The Director of the APM at the time was Trajano Andrade, an influential local businessman. Andrade used the vision of Manta-Manaus to market the Manta port to international investors, promising that the interoceanic corridor would transform Ecuador into "the key node of... commercial exchange between the Amazon basin and the Pacific rim" (Autoridad Portuario de Manta 2006). In 2006 he secured the concession of the port to Hutchinson Port Holdings, the world's leading port operator, in a deal that committed Hutchinson to invest \$US523 million in the port over a 30-year period (Business News Americas 2007). He also promoted the project to the Ecuadorian Minister of Economy and Finance, Rafael Correa, who then incorporated it into his

\footnotetext{
${ }^{6}$ Augusto Celís, Managing Director of Corporación Ecuatorial Amazónico. Interview: 03 March 2015, Quito, Ecuador.
} 
2006 presidential election campaign, in which he pledged to end neoliberalism, and to implement a 'transformation of the productive matrix', which would deliver the Amazonian region of the country from the socially and ecologically catastrophic consequences of the oil industry (Wilson and Bayón 2015). Manta-Manaus was a key component of this 'post-neoliberal' development strategy, and Correa promised to complete the corridor by 2011 (Medalla 2006).

Correa won the election, and appointed Andrade as Minister of Transport and Public Works, with the task of implementing Manta-Manaus. Andrade presented the project to the Brazilian President, Luis Inácio Lula de Silva, at a summit in Brasilia in 2007. ${ }^{7}$ Manta-Manaus, he argued, would provide a direct link between China, which was now Brazil's largest trading partner, and the booming free trade zone of Manaus, replacing the existing route via the Panama Canal and Belem, and reducing transport times between Chinese factories and Brazilian assembly plants by up to twenty days. The same route, would also facilitate the export of soya and other primary commodities from the Brazilian Amazon to the vast emerging markets of East Asia. Lula was convinced, and approved a US\$600 million credit line through Brazil’s National Development Bank (BNDES) to finance the construction of the corridor. Manta, Lula declared, would become "the gateway between Asia and Brazil" (quoted in Medalla 2008).

In 2008, Providencia was selected as the intermodal port of Manta-Manaus. The minister who took the decision recalls that he had been convinced to do so by Carlos Fermín, who he describes as "a visionary who was here in Ecuador without any infrastructure or any support from the state, pushing his dream". ${ }^{8}$ Over the course of the following years, the Ecuadorian section of MantaManaus evolved to include 810 kilometres of new or improved roads; the Manta and Providencia ports; a free trade zone in Manta; new airports in Manta, Latacunga, and Tena; and the dredging

\footnotetext{
7 Trajano Andrade, Director of Manta Port Authority 2004-2007, Minister of Transport and Public Works January-July 2007. Interview: 16 March 2015, Manta, Ecuador.

${ }^{8}$ Jorge Marún, Minister of Transport and Public Works 2007-2009. Interview: 13 March, Guayaquil, Ecuador.
} 
of the Napo to make it navigable by large cargo vessels (Ministerio de Relaciones Exteriores 2010). The environmental impacts of such major geographical upheavals were questioned by some indigenous and ecological groups (Bonilla 2010). But most of those living along the corridor were enthusiastic about its promise of market integration and geographical freedom. One inhabitant of Providencia, where the new intermodal port is being constructed, recalls having been "impressed" and "inspired" by a business associate of Carlos Fermín, who visited the community with a laptop computer on which he showed them a video with computerized images of "great ships" arriving at Providencia by river. His aunt then awoke him late at night, telling him that she had just had a "spectacular" dream about Manta-Manaus, and insisting that they purchase land along the riverbank. ${ }^{9}$ The leader of the Siekopai, an indigenous nationality based near Providencia, also told us that he hoped that the corridor would create economic opportunities, which the community would be able to "take advantage of by creating companies". Manta-Manaus, he declared, was "the dream of the Siekopai nation". ${ }^{10}$

In July 2011, true to his election promise, Correa launched the Manta-Manaus corridor, embarking on the maiden voyage down the Napo in a barge filled with Ecuadorian products and draped in an enormous national flag (El Telégrafo 2011). In a triumphant speech delivered a few kilometres upriver from Providencia, Correa announced that "Today we are taking a firm and irreversible step towards the fulfilment of a dream: Manta-Manaus. This is a great part of the country's future... And we are determined that this dream will be a success." ${ }^{11}$ He then boarded the barge and set off downriver. An hour or so later he disembarked at Providencia, and allowed the maiden voyage to continue on its way. Sitting in his porch above the Napo in 2015, Fermín recalled the President's arrival in Providencia as a moment of personal triumph: "The whole project, President Rafael

\footnotetext{
${ }^{9}$ Landowner in Providencia. Interview: 11 February 2015, Shushufindi, Ecuador.

${ }^{10}$ Elias Piaguaje, leader of the indigenous nation of the Sekopai. Interview: 10 February 2015, Providencia.

${ }^{11}$ Correa's speech at the launch of Manta-Manaus can be seen here: https://www.youtube.com/watch?v=tQpwyHo1E3E (accessed 21 May 2015)
} 
Correa and Carlos Fermín! ... No-one can take this project away from me! I've never turned away from the decision that I took in 2004... I know it's good and I know it's the future... It is a reality that is underway, and nobody can stop it!"12 Sitting with him that evening, surrounded by the cacophonous jungle and the silent river, it seemed that the Amazon really was a magical place in which the wildest dreams could be transformed into reality...

\section{The annihilation of time by space}

The creation of Manta-Manaus demonstrates the role of fantasy in the constitution of social reality. The project is premised upon the reduction of transportation times between East Asian production sites and the assembly lines of Manaus, and is justified in terms of "less time, less cost" in comparison to alternative global trade routes (Ministerio de Relaciones Exteriores 2010). As such, it is directly expressive of the logic of "the annihilation of space by time" (Marx, quoted in Harvey 2001: 244) through which capital drives towards "the equalization of geographical differences and the shrinking of world space" (Smith 1984: 158). However, as we have seen, this subordination of social space to the law of value has been framed by dreams of national development, global integration, and geographical freedom. Without this web of fantasies, and its capacity to mobilize the actions and configure the attitudes of entrepreneurs, politicians, and local populations, Manta-Manaus would not have come into existence. These fantasies disavow capital's drive towards the spatial unification of the world market, by representing this abstract logic in terms of the social good. But they also repress the internal contradiction of this logic, through which the tendency towards equalization enters into conflict with an equally powerful drive towards differentiation (Smith 1984: 132-174). State representations of Manta-Manaus depict it as an arrow hurtling across Ecuadorian space in a clean and rigid line. ${ }^{13}$ But strategies of

\footnotetext{
${ }^{12}$ Carlos Fermín. Interview: 09 February 2015, Providencia.

${ }^{13}$ This representation can be seen at http://www.puertodemanta.gob.ec/wpcontent/uploads/2012/02/PROCESO-DELEGACI\%C3\%93N-PUERTO-MANTA.pdf (accessed 21 May 2015).
} 
equalization threaten to disrupt the value relations of the spaces onto which they are projected, and tend to generate forceful localized resistances, expressed in inter-capitalist competition and geopolitical tensions (Harvey 1982: 413-445). Such representations also elide the potentially disruptive agency of the natural conditions that they seek to materially produce and ideologically erase (Moore 2015: 2-3). As we will see in this section, each of these dimensions of differentiation has contributed to the shattering of the fantasy of Manta-Manaus.

These contradictions began to assert themselves in October 2008, when Correa ordered troops to seize the assets of the Brazilian construction company Odebrecht, in response to alleged negligence in the construction of a hydroelectric dam (Rumsey 2008). This decision coincided with the outbreak of the global financial crisis, which resulted in a significant decrease in Pacific Ocean trade. Under these conditions, Hutchinson began to scale back its investments in the port of Manta, leading Correa to threaten to cancel the concession in January 2009. Fearing a repeat of the Odebrecht expropriation, and seeing an opportunity to escape a potentially unprofitable venture, Hutchinson responded by abandoning the concession (Wikileaks 2009). ${ }^{14}$ Meanwhile, Brazil responded to the expropriation of Odebrecht by cancelling the US\$600 billion credit line that Lula had established for the construction of Manta-Manaus, and shifting its investment to an alternative interoceanic corridor between Manaus and the Peruvian port of Paita (Medalla 2009). The Correa administration was thus obliged to finance Manta-Manaus itself. This investment was enabled by an immense increase in state oil revenues generated by a renegotiation of foreign oil contracts in the context of a global commodities boom (Ruiz 2013: 56-68). ${ }^{15}$ By the end of 2014, the majority of the road and airport infrastructure for the corridor was in place, at a total cost of

\footnotetext{
${ }^{14}$ Container traffic in and out of Manta has since collapsed, dropping from 38,749 Twenty-Foot Equivalent Units (TEUs) a year in 2005, when Hutchinson was bidding for the concession, to a mere 532 TEUs during the whole of 2014 (Autoridad Portuaria de Manta 2015).

${ }^{15}$ Public investment in Ecuador rose from US\$1.1 billion in 2001 to US\$9.5 billion in 2011 (Dávalos and Albuja 2014: 157-158).
} 
over US\$1 billion, illustrating the seemingly magical power of oil rents to produce "dazzling development projects that engender collective fantasies of progress" (Coronil 1997: 4). ${ }^{16}$

Yet far from the annihilation of space by time, the materialization of Manta-Manaus has taken the form of the annihilation of time by space. The road from Manta to Providencia is not a straight line slicing surgically through the national territory, as state representations suggest, but an interminable series of steep and narrow switchbacks bombarded with rock-falls and frequently blocked by landslides, which climbs to an altitude of over 3,000 metres from the Pacific to the Andes, before descending back to near sea-level in the Amazon. Unable to flow freely through this contorted landscape, capital has moved elsewhere. The vast majority of container traffic now enters Ecuador via the southern port of Guayaquil, and ascends the Andes by a less tortuous route, rendering redundant the road from Manta to the mountains. Guayaquil is Ecuador's main port, and its progress in the wake of Manta's demise has fueled a widespread conspiracy theory, according to which Guayaquil's mercantile elite colluded with Hutchinson to undermine Manta's development, in "a minutely detailed and coldly calculated strategy" (Vincent 2010: 81).

In contrast to the Promethean promise of its official representations, this tangle of political controversies, economic conflicts, and geographical obstacles has transformed Manta-Manaus into a distinctly unattractive investment opportunity. In the words of a representative of the Ecuadorian planning ministry, "We've invested and invested but nobody wants to buy... none of it is profitable - neither the ports nor the airports nor Manta-Manaus itself".${ }^{17}$ The newly constructed airport of the Amazonian city of Tena, for example, cost US\$50 million, but an internal

\footnotetext{
${ }^{16}$ An official projection made in 2010 costs total road construction for Manta-Manaus at US\$876.481 million (Ministerio de Relaciones Exteriores 2010). Airport investments in Tena, Latacunga and Manta have totaled approximately US\$100 million, while state investment in the ports of Manta and Providencia amounts to US\$156 million (Ministerio de Transporte y Obras Públicas 2015). According to these figures, by 2015, total state expenditure on the infrastructure for Manta-Manaus stood at approximately US\$1,132,000,000.

${ }^{17}$ Representative of the National Secretariat of Planning and Development (SENPLADES). Interview: 21 November 2014, Quito.
} 
government report on Manta-Manaus lists total metric tonnes of cargo handled at Tena in 2014 as “0” (Ministerio de Transporte y Obras Públicas 2015: 2). In 2015, the airport only received one passenger flight a day, which arrived from Quito, and was being run at a loss by the state airline. ${ }^{18}$ In 2016, this flight was cancelled, and the airport now stands empty (Ecuavisa 2016). Another new airport in the highlands of Latacunga received only two flights a day in 2014, while the Manta airport lacked any international cargo traffic. Its only client, a Chilean airline, was expelled when it was discovered to be using the airport, not for transporting Ecuadorian exports, but only to fill up on subsidised fuel before continuing to Miami. ${ }^{19}$

The difficulties confronting the maritime, terrestrial and aerial dimensions of the multimodal corridor have been compounded by the realization that the Ecuadorian section of the Napo is not navigable by ships large enough to make such a venture profitable for international commerce. This stretch of the river is shallow and meandering, and its course is continually altered by silt washed down from the Andes (ECLAC 2006). A 2010 study conducted by the Inter-American Development Bank (IDB) found that the dredging of the Ecuadorian section of the Napo would have to be a constant procedure involving the annual movement of "over 15 million metric tonnes" of sediment, which would be technically complex, environmentally destructive, and "economically unsustainable" (quoted in Laboratorio Manta-Manaos 2014: 31-32). Owners and operators of the local shipping fleet told us that even the small barges that work the Ecuadorian Napo would frequently run aground on hidden sandbanks, and local inhabitants mocked the idea that the river could be navigated by large cargo vessels. In the words of one peasant farmer, who has lived all his life on the banks of the Napo, "Fighting nature is impossible... They can clean it up and cut a channel if they like, but this river is a total rebel (bien bandido)!"20 Others agreed,

\footnotetext{
${ }^{18}$ Mario Paredes, Junior Minister of Civil Aeronautics, Ministry of Transport and Public Works (MTOP). Interview: 06 February 2015, Quito.

${ }^{19}$ Mario Paredes, Interview: 6 February 2015, Quito.

${ }^{20}$ Peasant farmer living near Providencia. Interview: 26 February 2015, Providencia.
} 
describing the Napo as "very treacherous", 21 and "like a woman. If you don't know her well, you won't get anywhere".$^{22}$ The only person who remained convinced of its navigability was Carlos Fermín, whose entire interoceanic fantasy had been founded on this passionate belief, and who dismissed all arguments to the contrary as the devious work of "an ugly black hand". ${ }^{23}$

At the launch of Manta-Manaus in 2011, Correa had stood on the banks of the Napo and declared that "If nature opposes our designs, we will fight against her and we will win". ${ }^{24}$ Yet the maiden voyage only served to confirm the project's intrinsic geographical unviability. A member of the presidential entourage recalls that the journey downriver was "like riding a bicycle. The slowness of the Napo is enough to drive you insane!" ${ }^{25}$ After Correa had disembarked in Providencia, the maiden voyage turned the next bend in the river and became stranded on a sand bank, where it remained for the next five days (El Comercio 2011). It took eighteen days to reach the Colombian city of Leticia, where the voyage was abandoned, with Manaus still over 1,000 kilometres away. Slavoj Žižek defines utopia as "a belief in the possibility of a universality without its symptom" (Žižek 1989: 23). Manta-Manaus is utopian in this sense, to the extent that it has pursued the universality of global equalization in abstraction from the contradictory tendency towards differentiation, which is inherent to the dynamics of the capitalist production of space. Through the process of its implementation, this repressed tendency has asserted itself in multiple symptoms: Hutchinson's departure; Odebrecht's expulsion; Guayaquil's conspiracy; the obstinate bulk of the Andes; the wanton caprices of the Napo... The dream of Carlos Fermín has thus collided with the Real that it denies. Like Fitzcarraldo, who hauled a steamship over a mountain, only for

\footnotetext{
${ }^{21}$ Inhabitant of Providencia employed at one of the private ports. Interview: 26 February 2015, Providencia.

22 Augusto Celís. Interview: 03 March 2015, Quito.

${ }^{23}$ Carlos Fermín. Interview: 09 February 2015, Providencia.

${ }^{24}$ The speech can be seen at: https://www.youtube.com/watch?v=tQpwyHo1E3E (accessed 21 May 2015).

${ }^{25}$ Aurora Valle, Director of the Manta Chambers of Commerce: Interview 17 March 2015, Manta.
} 
the river to carry it back to where he had started, Fermín's ambitions would appear to be "subservient to a larger destiny over which he has no ultimate control" (Prager 2003: 23).

\section{The soul of capital}

The story of Manta-Manaus might seem to have reached its logical conclusion at this point, having illustrated the tendency for ideological fantasies to be undermined by the antagonisms that they repress and disavow. But the relationship between fantasy and the Real is more complex than such a conclusion would suggest. According to Freud, a dream is "a compromise between the demands of a repressed impulse and the resistance of a censoring force in the ego" (quoted in Nagera 1969: 17). In its deepest form, fantasy operates in a similar way, by functioning as "the screen that separates desire from drive" (Žižek 1997: 43). We have seen how state representatives and speculative entrepreneurs have been gripped by desires for national development and market integration, which have functioned to disavow the uncontrollable dynamics of uneven geographical development into which these fantasies have been thrown. But beneath the level of desire, such fantasies also mask what Freud identified as death drive, understood as "a blind persistence which follows its path with utter disregard for the requirements of our concrete lifeworld" (Žižek 2008b: xvi). In capitalist societies, this alien drive can be equated with the accumulative imperative of capital itself. In Marx's memorable phrase, "As capitalist, he is only capital personified. His soul is the soul of capital. But capital has one sole driving force, the drive to valorize itself, to create surplus value" (Marx 1976: 342). This is not to suggest that everything is determined by the logic of capital, but only to emphasise that state spatial strategies are structured by their utility for capital accumulation, and that "value, acting with the force of an elemental natural process, [ultimately] prevails over the foresight and the calculation of the individual capitalist" (Marx, quoted in Harvey 2013: 70). 
The relationship between phantasmatic desire and the Real of the drive can be illustrated by the case of the intermodal port of Providencia. Following its ill-fated maiden voyage, Manta-Manaus was removed from the triumphant discourses of the Correa administration, as if in silent $r$ acknowledgment of its deserted highways, vacant airports and unnavigable watercourses. Yet the Ecuadorian government quietly continued with the construction of the port at Providencia, and the road connecting the port to the national highway network. The completion of the road, in February 2014, triggered a rush of land speculation in Providencia, and seven private ports now line the riverbank. Despite the construction boom, however, this previously isolated community remains without water or sanitation, and a constant flow of diesel-spilling barges in and out of its private ports has rendered the river water undrinkable. The privatization of the riverbank has excluded the local kichwa indigenous population from access to much of the river, and the waves cast by high-speed launches have made travel on their dugout canoes a dangerous undertaking. On the outskirts of Providencia, we spoke to a man leading a mule laden with bananas for sale in the local market. Had he heard of Manta-Manaus? "Oh yes," he replied, "I've heard enough about that to send me psychotic! (iPsicotizado con eso!) ... They said it was going to be a good project that would bring benefits for the community. Of course there are benefits, but only for people with lots of money that have come here to take advantage of it. The people from here can't even enter [the port], even though this is our territory." He loaded the bananas back onto his mule and went on his way with a sarcastic shout of defiant ambition: "To Manaus!"26

The burgeoning entrepreneurial activity in Providencia would seem to suggest that Manta-Manaus is finally beginning to function as a commercial corridor, if only at the expense of the local population. But the businesses that have established themselves in Providencia are not concerned with international trade. They are oil companies. During our initial visits to Providencia, one of the

\footnotetext{
${ }^{26}$ Peasant farmer living near Providencia. Interview: 26 February 2015, Providencia.
} 
private ports was filled with hundreds of huge steel pipes destined for Block 43, also known as ITT, a rich and highly controversial oil field that is partly located within the Yasuni National Park, which is one of the most biodiverse places on Earth. ${ }^{27}$ During his first years in government, Correa promoted the Yasuni-ITT Initiative, which sought compensation from industrialised nations in exchange for leaving the ITT reserves underground. Like Manta-Manaus, this initiative was part of a government strategy for the 'transformation of the productive matrix' away from dependency on Amazonian oil resources (Purcell et al 2016). Over the course of his time in office, however, Correa's legitimacy has become increasingly dependent on the maintenance of high levels of public investment, which have continued to be heavily dependent on oil revenues. Since 2009 , the government has opened a series of bidding rounds for the concession of new oil blocks, many of which are located in socially and environmentally sensitive areas, while signing contracts with foreign multinationals for the joint exploitation of Ecuador's mature reserves (Escribano 2013).

In August 2013, Correa announced the exploitation of Block 43, provoking national protests and international condemnation (Economist Intelligence Unit 2014). By the time the announcement was made, the road to Providencia was almost complete. Block 43 occupies a vast extension of territory adjacent to Peru, and is accessed via the Napo. Providencia was now the closest point to Yasuni accessible by road, and the newly constructed highway, designed for the heavy container traffic of Manta-Manaus, was ideal for the transportation of the materials required to construct the infrastructure for Block 43. This has led to allegations that the Correa administration had decided to exploit Block 43 long before the official declaration was made, and that Manta-Manaus was merely a discourse to disguise the construction of the transport infrastructure that the controversial new oil block would require. In the words of an influential local politician, "It's a

\footnotetext{
${ }^{27}$ Robin Draper, General Manager of Conduto in Ecuador. Interview: 24 February 2015, Quito.
} 
camouflaged way of doing things, in my opinion. They say they are going to make the port for Manta-Manaus and instead it is serving the oil industry for the exploitation of Yasuni."28

Regardless of whether such motives exist in the case of Providencia, however, they cannot account for the concession of the port in Manta, the construction of a highway over the Andes, or the opening of airports across the breadth of the national territory, all of which are included in Manta-Manaus, but none of which are functional for the oil industry. In this context, the repurposing of Providencia for the expansion of the oil frontier can be explained, not as a deliberate state strategy, but as a material expression of the inability "of state policies to determine the modality and course of accumulation within each national space of valorisation", and their ultimate subordination to the logic of "the accumulation of the total social capital at the global scale" (Grinberg and Starosta 2015: 240). The Ecuadorian Amazon has been incorporated into global capital accumulation on the basis of its oil reserves, and the transformation of Providencia into an oil port is ultimately expressive of the power of this drive, which is screened by the modernizing governmental vision of Manta-Manaus, not necessarily as a strategic diversion, but rather as an ideological fantasy that "creates what it purports to conceal” (Žižek 1997: 6).

The capitalist iteration of this fantasy conceals a similar subordination to the Real of the drive. The entrepreneur who had been inspired to establish his shipping company by the launch of MantaManaus explained that the failure of the interoceanic corridor had forced him into the oil business: "It wasn't what we had planned to do", he said, "but there is no alternative. If you don't invest in the oil business, you can't invest in anything". ${ }^{29}$ Another operator told us that he had tried to diversify into tourism with the refurbishment of an old ferry to serve as a floating hotel. There was no demand for the service, and he was hiring it to one of the oil companies, to house employees

\footnotetext{
${ }^{28}$ Guadalupe Lori, Prefect of Coca. Interview: 24 March 2015, Coca.

${ }^{29}$ Juan Carlos Hidalgo, owner of the Hidalgo shipping company. Interview: 24 March 2015, Coca.
} 
working on the construction of ITT. ${ }^{30}$ Two dredging machines were busily working the Napo. But instead of clearing channels for interoceanic trade, they were digging up sand to make concrete for Block 43. ${ }^{31}$ Again, these decisions do not imply that the interoceanic fantasy is a smokescreen for a conspiratorial agenda, but rather illustrate the extent to which capitalist desires are ultimately subordinated to the accumulative drive of capital itself.

This can be further illustrated by returning to the case of Carlos Fermín, whose dream would now seem to lie in ruins. In 2014, the Correa administration expropriated him of most of his land for the construction of the official port, for which he claims to have received no compensation. Reflecting on the destruction of Providencia, Fermín told us that "It hurts my soul to see this disaster. No money could make up for them ruining a project that I have struggled so hard to make happen". According to him, "Everyone has come here to speculate, to make money off the government project... [But] I'm not going to sell my soul to the devil. I prefer to be with God and sleep in peace". For this reason, he explained, he had decided to found an evangelical church in Providencia, in which he now preaches "the marvels of the project and the word of God" to their local congregation. ${ }^{32}$ But several inhabitants of Providencia told us that Fermín had broken the promises of development that he had made to the community, and that "He wants everything for himself." ${ }^{33}$ The owner of one of the private ports described Fermín as "a snake charmer", and accused him of using his church to extort favours from incoming businesses. "In the Amazon there is a great fear of the [indigenous] communities", he explained. "Businesses are scared. Oil companies are scared. [Fermín] frightens anyone who arrives [in Providencia, saying] 'If you don't do this or that [for me] I'll throw you to the community, and the community trusts in me.'”34

\footnotetext{
${ }^{30}$ Rafael Galeth, owner of Servicios Petroleros Galeth (SEPEGA). Interview: 06 April 2015, Coca.

${ }^{31}$ Luis Cordobillo. Vice-Mayor of Aguarico. Interview: 26 March 2015, Tiputini, Ecuador.

${ }^{32}$ Carlos Fermín. Interview: 10 February 2015, Providencia.

${ }^{33}$ Peasant farmer living near Providencia. Interview: 26 February 2015, Providencia.

${ }^{34}$ Owner of one of the private ports in Providencia. Interview: 02 March 2015, Quito.
} 
As with the conspiracy theories surrounding the failure of the port of Manta and the construction of the road to Providencia, these competing narratives contribute to the inextricable entanglement of fantasy and reality through which the spaces of capital are produced, and the accumulation of capital is achieved. Amidst this confabulatory morass of dreams and nightmares, Carlos Fermín has abandoned his interoceanic fantasy, and has established a stone crushing factory in the centre of Providencia, which is supplying the raw materials for the construction of Block 43. Such a prosaic conclusion should come as no surprise. The imperative to accumulate is the drive that animates the fantasies of the capitalist, and these fantasies must ultimately be sacrificed on the altar of accumulation itself. This is the Real of Capital, which "always chooses the right time to produce those people by whom it feels represented sympathetically... the class of capital owners and entrepreneurs who, with devastatingly progressive energy, blow to pieces all stationary conditions, and cause all solid states to evaporate" (Sloterdijk 2013: 68).

\section{The reality of dreams}

Over US\$1 billion has been invested by the Correa administration in the construction of MantaManaus. The aim was to integrate Ecuador into transnational circuits of capital, by opening a highspeed channel for the accelerated circulation of commodities between East Asia and Brazil, as part of the 'transformation of the productive matrix', through which Ecuador would replace its dependence on oil exploitation with a modern, technologically-advanced economy. But the failure to develop the port of Manta and the unviability of the Ecuadorian Napo as a commercial waterway have resulted in the stark absence of global commerce passing through the corridor. To date, not a single container has made the journey from Manta to Manaus. Meanwhile, Peru is advancing in the construction of its own interoceanic corridor. The Panama Canal is being expanded, and another interoceanic corridor is under construction in Nicaragua, backed by US\$50 billion of Chinese capital (Fonseca 2015; Partlow 2015). Manta-Manaus would therefore seem to 
constitute a classic case of a failed spatial fix, in which overaccumulated capital in the form of oil rents has been channelled into the production of a new economic space that has been rejected by capital. But this is not the whole story. Capital has not simply rejected the project, but has repurposed its infrastructures for the expansion of the oil frontier. Manta-Manaus is therefore functioning to reinforce the economic model that it was supposed to be replacing, and this interoceanic fantasy has itself been materialized by the oil revenues through which rentier capitalism "casts its spell over audience and performers alike" (Coronil 1997: 5).

This paper has traced the twists of this paradoxical tale, in the development of a fantastical materialism, understood as a theoretical and methodological approach to the intertwining of fantasy and reality in the capitalist production of space. Each twist of the story has unfolded a specific involution of this entangled relationship. The first twist demonstrated the fantastical constitution of reality, by showing how a seemingly sterile technocratic strategy for the construction of a multimodal transport corridor has been animated by an overgrowth of dreams of market integration and geographical freedom. These fantasies captured the imaginations of politicians, entrepreneurs, and local populations, and without them the project would have been impossible. The second twist illustrated the ways in which such ideological fantasies are undermined by the Real that they deny. The fantasy of Manta-Manaus provided a disavowed expression of the drive of capital towards spatial homogenization and the annihilation of space by time, while repressing its contradictory tendencies towards fragmentation and differentiation. Through the implementation of the corridor, however, these contradictions have reasserted themselves in the forms of inter-capitalist competition, geopolitical rivalry, and the recalcitrance of nature. The third twist revealed the complexity of the relationship between fantasy and the Real, in which phantasmatic desires not only disguise the traumatic dimensions of an external reality, but also mask an internalized drive. Beyond their fantasies of insatiable markets and accelerated modernization, individual capitalists and the capitalist state are ultimately 
subordinated to the imperative of the expanded reproduction of capital, expressed in the global law of value. The incorporation of Providencia into the economic infrastructure of the oil industry has unleashed a process of accumulation by dispossession that has destroyed the dream of Manta-Manaus. But the shattering of this fantasy has contributed to sustaining the economic growth through which the Correa administration has been politically legitimated, while guaranteeing the solvency of Carlos Fermín and other entrepreneurs, who were inspired to invest in the dream of an interoceanic corridor, but who have since been obliged to abandon this dream and adapt their investments to the accumulative imperative of the oil boom. The Real of Capital thus advances through the creative destruction of its own fantasies. This, to quote Fitzcarraldo once more, is "the reality of dreams". ${ }^{35}$

This paper has sought to demonstrate 'the reality of dreams' in two senses of the term: the structuring of socio-spatial reality by ideological fantasies, and the distortion of such dreams in the process of their realization. In developing this line of argument, we have focused on the fantasies of state and capital, and a multitude of subaltern struggles and experiences have faded into the background. Here we conclude by drawing attention to one such struggle, which adds a final twist to our tale, and which opens political questions that we have begun to address elsewhere (Wilson and Bayón 2016). In 2010, the kichwa population of Providencia formed an association called Sumak Ñambi, which roughly translates as 'Gorgeous Road', conveying the hopes that at that time were still embodied in the highway. Yet instead of opening a world of freedom and integration, as we have seen, the arrival of the road confronted the community with imminent dispossession. Faced with the shattering of their fantasy, Sumak Ñambi responded by creating an autonomous urban project to defend what remained of their land. In 2015, the opportunity to realize their plan unexpectedly presented itself, when a transport company attempted to purchase the riverside

\footnotetext{
${ }^{35}$ At the Jesuit mission at which Fitzcarraldo passes the night on his way upriver to the mountain, a monk tells him that "Ordinary life is only an illusion, behind which lies the reality of dreams".
} 
land of the community, with the aim of creating yet another private port. Sumak Ñambi made a counter-proposal: in exchange for the lease of a space for the port, the company would cut and surface the roads for their town. Within two months the roads had been sliced through the jungle, with the felled trees providing the wood for the construction of the houses. Every weekend Sumak Ñambi gathered in collective community labour, and the town began to take form. ${ }^{36}$

At the same time, a collapse of the international oil price was driving Ecuador into recession. By the end of 2015, the construction of the great port of Manta-Manaus had been abandoned. When we last visited Providencia, in June 2016, the half-completed official port was overgrown with weeds, the transport company had gone bankrupt, and even Carlos Fermín was nowhere to be found. Yet the streets and houses of Sumak Nambi were quietly flourishing. Amidst the ruined fantasies of state and capital, the humble case of Sumak Ñambi suggests that utopian possibilities are generated, not by dreaming of 'enchanted' worlds, but by confronting the destruction of all such dreams. As Žižek concludes: "The true utopia is when the situation is so without issue, without a way to resolve it within the coordinates of the possible, that out of the pure urge of survival you have to invent a new space" (Žižek 2011). From the perspective of a fantastical materialism, in other words, utopia begins where fantasy ends.

\section{References}

Ainsworth, Philip (1934) "Gonzalo Pizarro and Francisco de Orellana" The Hispanic American Historical Review 14:3 pp. 275-295

Arboleda, Martin (2016) "Spaces of Extraction, Metropolitan Explosions: Planetary Urbanization and the Commodity Boom in Latin America" International Journal of Urban and Regional Research 40: 1 pp. 96-112

Autoridad Portuaria de Manta (2006) Eje Multimodal Pacífico-Atlántico Ecuador-Brasil (PowerPoint presentation)

Autoridad Portuaria de Manta (2015) Informe Anual 2014 (internal document)

Bennett, Jane (2001) The Enchantment of Modern Life Princeton: Princeton University Press

Berman, Marshall (1982) All That Is Solid Melts into Air London: Penguin

Bonilla, Omar (2010) "The Manta-Manaus Project: Nature, Capital and Plunder" in CEECEC, The CEECEC

Handbook: Ecological Economics from the Bottom Up pp. 7-23 http://www.ceecec.net/wp-

content/uploads/2010/09/HANDBOOK v2.pdf (accessed 21/05/2015)

\footnotetext{
${ }^{36}$ The information in this section is based on participant observation undertaken during several visits to Providencia in 2015, when we collaborated with Sumak Ñambi on their urban strategy.
} 
Brenner, Neil (2013) "Introduction: Urban Theory without an Outside" in Neil Brenner (ed.)

Implosions/Explosions: Towards a Study of Planetary Urbanization Berlin: Jovis pp. 14-35

Brenner, Neil and Christian Schmid (2015) "Towards a New Epistemology of the Urban?" City 19:2-3 pp. 151182

Browder, John O. and Brian J. Godfrey (1997) Rainforest Cities: Urbanization, Development and Globalization in the Brazilian Amazon New York: Colombia University Press

Business News Americas (2007) "Government officials discuss Manta-Manaus corridor financing" Business

News Americas 20 April 2007

http://www.bnamericas.com/news/infrastructure/Govt officials discuss Manta-

Manaus corridor financing (accessed 21 February 2015)

Coronil, Fernando (1997) The Magical State: Nature, Money and Modernity in Venezuela Chicago: University of Chicago Press

Dalakoglou, Dimitris and Penny Harvey (2012) "Roads and Anthropology: Ethnographic Perspectives on Space, Time and (Im)Mobility" Mobilities 7:4 459-465

Davalos, Pablo and Verónica Albuja (2014) "Ecuador: Extractivist Dynamics, Politics and Discourse" in Henry Veltmeyer and James Petras (eds.) The New Extractivism: A Post-Neoliberal Development Model or Imperialism of the Twenty-First Century? London: Zed pp. 144-171

Economist Intelligence Unit (2014), “CNE Rejects Yasunidos Petition" Economist Intelligence Unit 7 May 2014, http://www.eiu.com/industry/article/321791016/cne-rejects-yasunidos-petition/2014-05-08 (accessed 19/05/2015)

ECLAC (2006) Hacia un desarrollo sustentable e integrado de la Amazonía Santiago: ECLAC

Ecuavisa (2016) “Aerolínea comercial suspende operaciones en el aeropuerto con la tercera pista más grande del país" Ecuavisa 25 January 2016, http://www.ecuavisa.com/articulo/televistazo/noticias/126782-aerolinea-comercial-suspendeoperaciones-aeropuerto-tercera (accessed 29/04/2016)

El Comercio (2011) “El embarque por la ruta Manta-Manaos llegó a Leticia” El Comercio 03 August 2011, http://www.elcomercio.com/actualidad/negocios/embarque-ruta-manta-manaos-llego.html (accessed 22/05/2015)

El Telégrafo (2011) “Barcaza ecuatoriana abre la hidrovía del río Napo" El Telégrafo 16 July 2011, http://www.telegrafo.com.ec/noticias/informacion-general/item/barcaza-ecuatoriana-abre-lahidrovia-del-rio-napo.html (accessed 21/05/2015)

Escribano, Gonzalo (2013) “Ecuador's energy policy mix: development versus conservation and nationalism with Chinese loans" Energy Policy 57 pp. 152-159

Ferguson, James (1994) The Anti-Politics Machine: Development, Depoliticization ad Bureaucratic Power in Lesotho Minneapolis: University of Minnesota Press

Fonseca, Pablo (2015) "Nicaragua Constructs Enormous Canal, Blind to Environmental Cost" Scientific American 11 February 2015 http://www.scientificamerican.com/article/nicaragua-constructsenormous-canal-blind-to-its-environmental-cost/ (accessed 10/04/2015)

Grandin, Greg (2009) Fordlandia: The Rise and Fall of Henry Ford's Forgotten Jungle City New York: Picador

Grinberg, Nicolas and Guido Starosta (2015) "From Global Capitalism to Varieties of Centre-Leftism in South America: The Cases of Brazil and Argentina" in Susan J. Spronk and Jeffrey Webber (eds.) Crisis and Contradiction: Marxist Perspectives on Latin America in the Global Political Economy Leiden: Brill pp. 236-273

Harvey, David (1982) The Limits to Capital Oxford: Blackwell

Harvey, David (2001) Spaces of Capital: Towards a Critical Geography Edinburgh University Press

Harvey, David (2013) A Companion to Marx's Capital Volume 2 London: Verso

Harvey, Penny and Hannah Knox (2012) "The Enchantments of Infrastructure" Mobilities 7:4 pp. 521-536

Kanai, Juan Miguel (2014) "On the Peripheries of Planetary Urbanization: Globalizing Manaus and Its

Expanding Impact" Environment and Planning D: Society and Space 32 pp. 1-17

Jameson, Fredric (2014) “Autobiografía intelectual”, interview 09/12/2014, available at https://www.youtube.com/watch?v=6oKOW1Gl36s (accessed 20/01/2017)

Kochore, Hassan (2016) "The Road to Kenya? : Visions, expectations and anxieties around new infrastructure development in Northern Kenya" Journal of Eastern African Studies 10:3 pp. 494-510

Laboratorio Manta-Manaos (2014) Consultorio Territorial Amazónico Quito: Pontifica Universidad Católica de Ecuador (unpublished draft manuscript) 
Larkin, Brian (2013) "The Politics and Poetics of Infrastructure" Annual Review of Anthropology 42:3 pp. 327343

Marx, Karl (1976) Capital Volume One New York: Random House

Medalla, Eva (2006) “Pres-elect: Manta-Manaus corridor to be built by 2011" 15 December 2006, Business News Americas http://www.bnamericas.com/news/privatization/Pres-elect: MantaManaus corridor to be built by 2011 (accessed 21/02/2015)

Medalla, Eva (2008) "Manta-Manaus multimodal corridor to be ready in 2011" Business News Americas 09 October 2008 http://www.bnamericas.com/news/privatization/MantaManaus multimodal corridor to be ready in 2011 (accessed 21/02/2015)

Medalla, Eva (2009) "Proinversión plans to award Yurimaguas port concession by end-Sep" Business News Americas 21 April 2009

http://www.bnamericas.com/news/privatization/Prolnversion plans to award Yurimaguas port co ncession by end-Sep (accessed 21/02/2015)

Merrifield, Andy (2009) “Magical Marxism" Environment and Planning D: Society and Space 27 pp. 381-386

Merrifield, Andy (2011) Magical Marxism: Subversive Politics and the Imagination London: Pluto

Merrifield, Andy (2013) "The Urban Question under Planetary Urbanization" International Journal of Urban and Regional Research 37:3 pp. 909-922

Ministerio de Relaciones Exteriores (2010) Manta-Manaos: Eje Multimodal Bi-Oceánico (PowerPoint presentation)

Ministerio de Transporte y Obras Públicas (2015) Proyecto Multimodal Manta Manaos (internal government document)

Monte-Mor, Roberto (2013) “Extended Urbanization and Settlement Patterns in Brazil: An Environmental Approach" in Brenner, Neil (2013) Implosions/Explosions Berlin: Jovis pp. 109-120

Moore, Jason W (2015) Capitalism in the Web of Life: Ecology and the Accumulation of Capital London: Verso

Nagera, Humberto (1969) Basic Psychoanalytic Concepts on the Theory of Dreams London: Allen and Unwin

Partlow, Joshua (2015) "Can a Chinese Billionaire Build a Canal Across Nicaragua?" Washington Post 4 February 2015 http://www.washingtonpost.com/world/the americas/can-a-chinese-billionairebuild-a-canal-across-nicaragua/2015/02/03/e9cf3482-9aa5-11e4-86a3-1b56f64925f6 story.html (accessed 10/04/2015)

Perreault, Tom and Gabriela Valdivia (2010) “Hydrocarbons, popular protest and national imaginaries: Ecuador and Bolivia in comparative context" Geoforum 41 pp. 689-699

Purcell, Thomas F., Nora Fernández and Estefanía Martínez (2016) "Rents, Knowledge and Neostructuralism: Transforming the Productive Matrix in Ecuador" Third World Quarterly (available on Early View)

Prager, Brad (2003) "Werner Herzog's Hearts of Darkness: Fitzcarraldo, Scream of Stone and Beyond" Quarterly Review of Film and Video 20:1 pp. 22-35

Rose, Jacqueline (1996) States of Fantasy Oxford: Clarendon Press

Ruiz, Miguel (2013) “Parte I", in CDES, La Alquimia de la Riqueza: Estado, Petróleo, y Patrón de Acumulación en Ecuador Quito: CDES pp. 1-68

Russotto, Margara (2013) "Research interview: rethinking Amazonia and its discourses. An interview with Ana Pizarro" Canadian Journal of Latin American and Caribbean Studies 38:1 pp. 123-138

Sloterdijk, Peter (2013) In the World Interior of Capital Cambridge: Polity

Smith, Neil (1984) Uneven Development: Nature, Capital, and the Production of Space Oxford: Blackwell

Star, Susan Leigh (1999) The Ethnography of Infrastructure" American Behavioural Scientist 43 pp. 377-391

Vincent Bowen, Pedro (2010) Operación Callao: Vida, Pasión y Muerte de la Concesión de Puerto Manta Manta: Casa de la Cultura Ecuatoriana Benjamín Carrión

Watts, Michael (2011) "Petro-Violence: Community, Extraction and Political Ecology of a Mythic Commodity" in Nancy Lee Peluso and Michael Watts (eds.) Violent Environments Ithaca: Cornell University Press pp. 189-212

Wikileaks (2009) "Subject: Another One Bites the Dust: Hutchinson Port Holdings Abandons Manta Concession" Wikileaks Cable 06/03/2009 https://wikileaks.org/cable/2009/03/09GUAYAQUIL52.html accessed 21/05/2015

Wilson, Japhy and Manuel Bayón (2015) “Concrete Jungle: The Planetary Urbanization of the Ecuadorian Amazon" Human Geography 8:3 pp. 1-23 
Wilson, Japhy and Manuel Bayón (2016) “Black Hole Capitalism: Utopian Dimensions of Planetary Urbanization" City 20:3 pp. 350-367

Wilson, Japhy (2017) Perplexing Entanglements with a Post-Neoliberal State" Journal of Latin American Geography 16:1 (forthcoming)

Zamora, Lois Parkinson and Wendy B. Faris (1995) "Introduction: Daiquiri Birds and Flaubertian Parrot(ie)s" in Magical Realism: Theory, History, Community Durham: Duke University Press pp. 1-14

Žižek, Slavoj (1989) The Sublime Object of Ideology London: Verso

Žižek, Slavoj (1997) The Plague of Fantasies London: Verso

Žižek, Slavoj (2006) The Parallax View Cambridge: MIT Press

Žižek, Slavoj (2008a) Violence London: Profile

Žižek, Slavoj (2008b) For They Know Not What They Do London: Verso

Žižek, Slavoj (2011) "Slavoj Žižek on Utopia" Maquinas del Fuego 16/08/2011 http://maquinasdefuego.blogspot.com/2011/08/slavoj-zizek-on-utopia.html (accessed 01/08/2015) 